\title{
Beyond Banks' Capitalization: What Affects the Credit Lines?
}

\author{
Carmen Gallucci $^{1}$, Vincenzo Formisano ${ }^{2}$, Michele Modina $^{3} \&$ Rosalia Santulli $^{2}$ \\ ${ }^{1}$ Department of Management \& Innovation Systems, University of Salerno, Fisciano (SA), Italy \\ ${ }^{2}$ Department of Economics and Law, University of Cassino and Souithern Lazio, Cassino (FR), Italy \\ ${ }^{3}$ Department of Economics, Management, Society and Institutions, University of Molise, Campobasso (CB), Italy \\ Correspondence: Carmen Gallucci, Department of Management \& Innovation Systems, University of Salerno, 84084, \\ Fisciano (SA), Italy. Tel: 39-89-963-436. E-mail: cgallucci@unisa.it
}

Received: July 21, 2017

Accepted: August 9, 2017

Online Published: September 16, 2017

doi:10.5430/ijfr.v8n4p71

URL: https://doi.org/10.5430/ijfr.v8n4p71

\begin{abstract}
The present paper aims at investigating what affects the credit granting beyond banks'capitalization. It focuses on public and private firms' information available for the banks. We apply moderating regression models on panel data. Our sample is of 123 co-operative credit banks and more than 11,000 firms operating in Italy between 2012 and 2014, for 18,143 observations. Our main findings suggest that firms' profitability (public information) positively moderates the direct relationship between banks' capitalization and credit grants; differently, multiple banking, overdue payment and credit limit violation days (private information) negatively moderate the above-cited relationship. Finally, the conjoint moderating effect of public and private information proves to be negative, thus also firms with a good profitability are penalized in credit grant whether they do not take care the relationship with banks.
\end{abstract}

Keywords: bank-firm relationship, credit granting, bank capitalization, multiple banking

\section{Introduction}

The banking literature has emphasized the role of banks' capitalization in determining credit grants (among others, Paravisini 2008; Khwaja and Mian 2008; Schnabl, 2012). However, much other information is used by banks before to grant loans, in order to estimate borrowers' creditworthiness and firm's financial reliability. On the one hand, they base their analyses on firms' economic and financial aspects (such as leverage, cost of debt, working capital, asset turnover, and profitability), elaborating on accounting information gathered from balance sheets; this is publicly available information and is accessible by each bank that has a relationship with the firm. On the other hand, banks can have access to real-time signals, related to the specific services provided to the firms. This means they have the opportunity to take the decisions on credit grants also basing on some private information related to bank-firm relationship (Foglia et al., 1998; Fiordelisi et al., 2014; La Torre and Mango, 2012). In doing so, banks can catch eventual signals of financial distress in a timely manner, while accounting information is backward looking. Indeed, banks can observe this private information long before receiving the financial statements of a firm, which might later confirm that the borrower is in financial difficulty (Norden and Weber, 2010).

The purpose of this paper is investigating what affects the credit granting beyond banks'capitalization. Specifically, it aims at evaluating the contribution of several aspects related to firms' balance sheets information (public available information) and to the bank-firm relationships (private available information). First, it examines the single effect producted by each of them; then, it analyzes the joint effect of public and private information on credit grants. We apply moderating regression models on panel data. Our sample is of 123 co-operative credit banks and more than 11,000 firms operating in Italy between 2012 and 2014, for 18,143 observations. Dataset was provided by Centrale Rischi Finanziari (CRIF: Italian Credit Register), an Italian credit rating agency issuing ratings on Italian firms, instrumental in banks' and other financial institutions' evaluation of their portfolios, and by Centro Servizi Direzionali (CSD), an Italian consulting company of the co-operative banks. Further data about banks' balance sheets were also collected on Bureau Van Dijk Database Bankscope and merged with the main dataset.

Our main findings confirm that well-capitalized banks are less likely to generate strong procyclical changes in credit supply conditions through rationing (Schreft and Owens, 1991). Moreover, they suggest that firms' profitability (public information) positively moderates the direct relationship between bank's capitalization and credit grants; differently, multiple banking, overdue payment and credit limit violation days (private information) negatively 
moderate the above-cited relationship. Finally, the conjoint moderating effect of public and private information proves to be negative, thus also firms with a good profitability are penalized in credit grant whether they do not take care the relationship with banks.

Our work seeks to provide useful implications for theory and practice. First, it focuses the attention not only on banks' balance sheet, but also on firms' one. Moreover, it also considers the effect of firm-bank relationships (private available information). In so doing, it offers a useful implication for practitioners. As know, firms must give attention on their profitability, besides they have to adequately plan their relationship with banks, because is determinant in credit grants and a mistake in the relationship can reveals unprofitable.

The remainder of this paper presents a brief literature review on the issue, delineates sample and data, describes the methodology applied and discusses the main findings.

\section{The Effect of Publicly and Privatly Available Information on Credit Grants: A Brief Literature Review}

Previous empirical research has emphasized the role of banks' capital constraints in determining credit granting (Leone, 2003; 2005; Birindelli and Ferretti, 2011). Some of them (e.g., Paravisini 2008; Khwaja and Mian 2008; Schnabl, 2012) have suggested that bank liquidity shocks are transmitted to their customers through a change in lending. Maintaining a satisfactory degree of risk coverage allows banks to maintain investor confidence and attract external financing at low cost. It is essential to continue to ensure an adequate flow of credit to households and businesses. Well-capitalized banks are less likely to generate strong procyclical changes in credit supply conditions through rationing (Schreft and Owens, 1991). Therefore, banks' capitalization has a positive effect on supply of credit to corporate sector.

However, banks' capitalization is not the only condition influencing the credit lines. The credit lines are the maximum amount a bank commits to lend to a borrower over a given time horizon (Norden and Weber, 2010). Before to grant loans, banks need to carefully evaluate borrowers' creditworthiness and firm's financial reliability, on the basis of firms' publicly (firms' accounting information gathered from balance sheets) and privatly available information (related to bank-firm relationship). At a time of great uncertainty about the economic outlook and substantial weakness of both firms' and banks' balance sheets, banks could decide to cut credit lines to their clients indistinctly, or they might select the worst borrowers through a careful evaluation process. In this last case, it would be interesting to try understanding which firms suffer more difficulties in accessing credit. Numerous studies (e.g. Angelini et al., 1998; Guiso, 1998; 2006) have shown that the difficulties in obtaining credit are related to different business characteristics, such as size, sector of economic activity, fiscal conditions. Banks look mainly for businesses budget balances, using financial statement information. The advantage is twofold. First, balance sheets are publicly available and their content is verified by a third part. Second, these data provide a bunch of quantitative information, that help to predict possible default events influencing, in turn, banks' decisions about credit rationing. Rationing credit to firms with high growth prospects might affect the ability to make investments or undertake development paths. Instead, for businesses characterized by less solid financial condition of the difficulty of access to credit can undermine a balanced budget to determine the failure. Therefore, a careful selection in credit rationing is essential. Obviously, the presence of fragile financial condition is associated with a much higher probability of rationing average (Albareto and Finaldi Russo, 2012). A weak financial structure, characterized by a high level of indebtedness and a limited supply of capital, with a higher incidence of interest expenses, is a determinant of future default events (Modina and Pietrovito, 2014). Banks consider these aspects when they have to express a judgement about firm's financial reliability. Therefore, we believe useful to consider in our study not only the effect of banks' capitalization on credit grants, but also firms' profitability and indebtedness. Specifically, we formulate the following hypotheses:

Hypothesis 1a: Firms' profitability positively moderates the relationship between banks' capitalization and credit grants

Hypothesis 1b: Firms' leverage negatively moderates the relationship between banks' capitalization and credit grants

Over accounting information, banks can have access to real-time signals, related to the specific services provided to the firms and thus related to the bank-firm relationships (privately available information). Bank-firm relationship is a central theme of the economic and financial literature. It has been enhanced with new profiles of observation and ideas of analysis for the unfolding of the effects induced by the crisis: among the most significant events, the deterioration of the economy of credit conditions, the slowdown in growth of bank loans, the difficulties of enterprises in the management of payments from customers and in dealing with the sharp fall in demand (Birindelli and Modina, 2010). Specifically, with respect to bank-firm relationship, the present paper considers some hard 
information about the credit lines usage, such as the credit limit violations days and the overdue payments, and also firms' choices about multiple bank.

Banks have the advantage of extracting hard information from several sources that are specific to the relationship with a given firm. Information spillovers coming from past loans and checking account activities might help the bank in the selection process of firms that apply for a loan. Information on credit line usage helps banks to monitor borrowers (Norden and Weber, 2010). Previous empirical research, actually, have shown a significant relationship between credit lines usage and default (Jiménez et al., 2009; Gallucci et al., 2017a) leading banks to take in account this information before to grant loans. that defaulting firms have significantly higher credit line usage rates and line exposure at default values (ratio between actual drawn amount and a fraction of undrawn amount) up to five years before the default event occurs.

The use of multiple bank is explained by the modest information transparency of small businesses. The less information transparency tends to elevate the costs incurred in the screening and firm's performance monitoring phases. Theoretically, the founders could increase the price of the loan; in doing so, however it raises the chances of seeing not repaid the loan, because it attracts the riskiest borrowers (adverse selection) and/or encourages the borrower to take on riskier behavior (moral hazard). These two phenomena have an impact on the overall profitability of the loan, then the lender may decide not to raise beyond a certain threshold the rate of interest and act on credit rationing (Stiglitz and Weiss, 1981).

A possible solution to the problem of asymmetric information could be found in the long-run relationship between bank and company (relationship lending) (Sette and Gobbi, 2014). The banks have the facilities, knowledge and skills that would enable them to compensate for the higher information asymmetry than companies, especially the smallest. However, the ability of the banks in reading the growth potential of a company, even picking up weak signals of the so-called soft information, seems to have weakened during the crisis. Albareto and Finaldi Russo (2012) suggest that the difficulties to access to credit for vulnerable firms would also be extended to some companies from good potential. The problem is provided for the high fragmentation of banking relationships, which do not favor a solid relationship between banks and enterprises (De Mitri et al., 2010). Reduce fragmentation would benefit, in particular, innovative businesses, whose evaluation by external financiers is typically much more difficult. There is empirical evidence that a long-term relationship with a bank increases the probability that an undertaking innovative activities (Herrera and Minetti, 2007; Micucci and Rossi, 2012). Narrower banking relationships facilitate access to credit, particularly for companies characterized by better growth prospects; This result is consistent with the hypothesis that the more banks involved in the financing of companies to be in better information and have greater incentives to use them. Empirical evidence, finally, confirmed by recent results on the importance of relations with customers in preserving the hardening companies offer credit (cfr. De Mitri et al., 2010). A high concentration of loans held by the major banks is associated with a lower likelihood of rationing. In addition, the presence of more "close relations" has influenced the selection made by the banks: the growth potential of businesses was most relevant in facilitating access to credit. This finding may reflect the breadth of information available to more intermediaries involved in financing companies and the increased incentives to use them in the selection of customers.

In the light of these arguments, we suppose that building a solid relationship with one bank rewards the firms and, thus, formulate the following hypotheses:

Hypothesis 2a: A bad credit lines usage (credit limit violations days, overdue payments) negatively moderates the relationship between banks' capitalization and credit grants

Hypothesis 2b: Multiple banking negatively moderates the relationship between banks' capitalization and credit grants

Because publicly and privately information may have a different (positive or negative) effect on the relationship between banks' capitalization and credit grants, we ask to us which of them is prevalent. Probabily, the answer is in private information, because banks can observe this information long before receiving financial statements of a firm, which may later confirm that the borrower is in financial problems (Norden and Weber, 2010). Therefore, in order to investigate also the conjoint moderating effect of them, we formulate the following hypothesis:

Hypothesis 3: The conjoint effect of publicly and privately information negatively moderates the relationship between banks' capitalization and credit grants

\section{Data and Methodology}

In this section, we present sample and data and illustrate the methodology applied to test our hypotheses and our 
models.

\subsection{Sample, Data and Variables}

In this article, we consider balance sheet information at firm-level (public information) and firm-bank relationship data (private information), provided us by Crif, an Italian company specializing in credit information systems, offering to banks tools and solutions for the relationship with the customer management. In addition, we sought out balance sheet information at bank-level on Bureau Van Dijk Database Bankscope. Banks and firms in our sample are Italian. Nonetheless the restricted field of investigation, Italy is particular instructive, since firms are highly dependent on banks as relationship lenders and banking industry has been deeply affected by the global financial crisis (Rossi, 2013). Despite Italian bank industry has reduced dimensions for the real economy, because their activities are 2,7 times the GDP, significantly lower than other Countries, banks in our Country play an important role in financing firms. Bank debts represent more than $60 \%$ of firms' financial debts; in France, they are approximately $30 \%$ and in Germany are about $50 \%$.

The capital market has a limited weight and the use of bonds does not reach the $8 \%$ of firms' financial debts (Panetta, 2013). After the financial crisis, in Italy, firms registered a degree of much higher debt than in the past (Rossi, 2013). In the years preceding the crisis, they had increased the bank debt on average at a rate of more than 8 percent a year, thanks to favorable bank interest rates and lower rationing by banks. The dependence on the banking system was greater for smaller firms, for which the coverage of the investments with internal sources dropped by half. These companies have been always reluctant to raise venture capital, cause their family nature, and because the recourse to the capital market implies a high and permanent transparency in costs and, finally, for the tax advantages. After several years in which they had enjoyed relative easy to access to bank credit, these firms found themselves burdened with financial statements by a high debt both by historical standards and relative to other countries (Bugamelli et al., 2009). In addition, a sharp fall in income flows and a sharp lengthening of customer payment terms (Accetturo et al., 2011), which led many companies to postpone, in turn, payments to suppliers, interest payments and the repayment of bank loans.

The initial dataset of 226,000 observations included data from 124 co-operative credit banks. Co-operative banks, which in Italy cover the $7.2 \%$ of lending, are known to be close to the territory and careful to the needs of firms, especially small-sized (Baccarani et al., 2013). However, after the recent financial crisis, unprecedented in its global scale and severity, and due to the Basel Accords, they have had to review their strategies about credit granting. As known a drop in liquidity for banks may have a direct transmission effect on the supply of credit for firms (Iyer et al., 2013), thus this circumstance translated in credit rationing, also defined as "credit crunch" (Bernanke and Lown, 1991; Bofondi et al., 2013; Burlon et al., 2016). T Co-operative banks hey adopt the same commercial policies (Baccarani et al., 2013), which allows us to make a deep comparison, without suffering from scale problems. These banks lend more than 81,000 firms located in 103 Italian provinces and operating in 80 different industries. In particular, firms in our sample belong to the following six macro-industries: agriculture, commerce, transports and hotels, manufacturing, building and services. The majority (95\%) of the firms are productive firms, including limited companies, cooperative companies producing goods and non-financial services, and consortiums. Other included segments are holdings of non-financial groups and operating private holdings, managing and controlling a group of companies whose main activity is goods and services production. More than $80 \%$ of firms are limited liabilities companies and 5\% of them are limited companies. Firms are mainly located in the Centre-North of Italy (72\%) and only $28 \%$ of them is operating in the South.

From the initial sample provided by Crif, after checking for outliers, duplicates and missing values, and excluding financial services and the public administration sectors, the resulting sample consist of 11,083 firms and 123 co-operative banks, for 18,143 observations. For each bank, we collected balance sheet data on Bureau Van Dijk Database Bankscope and then merged them with the main Crif database using the unique bank identification number. Banks' equity in our sample is from 5,500 to 322,000 ; their assets are from 44,200 to 8,467,900.

As dependent variables, we consider the variation of credit grants. We measur it as difference in the level of lending between 2014 and 2013 and between 2013 and 2012 for each firm.

As main independent variable, we consider banks' capitalization, using the CET1 (Common Equity Tier 1), calculated as TIER1/Assets ratio. Moreover, we insert in the models public and private firms' information available for banks. Specifically, as public information, we consider firms' financial indicators. We had a set of possible variables constructed by Crif. In order to identify which of them insert in the moderating regression analyses, we followed a process made in two steps. First, we applied the variance inflation factor model (VIF) for each potential independent variable, selecting the variables not affected by multicollinearity problems (Chatterjee and Hadi, 2012); then, we 
applied the stepwise procedure (backward selection method) to identify the best combination of significant explanatory variables (Shin and Lee, 2002; Shin et al., 2005). At the end of the process, moving from a long list of about 60 indicators concerning several areas of firms' profile, we selected the following firms' balance sheet indicators: the return on asset (roa); the return on debt (rod); the return on equity (roe); and the leverage. Also with respect to the private available information, we had a set of possible variables constructed by Crif. We proceeded in the same way as above-mentioned and decided to consider as variables linked to bank-firm relationship the following ones: the number of relationship with different banks for each firm (multiple banking), the share of credit line given in a month on a checking account that is used by the borrower (credit line usage); the number of credit limit violation days on a checking account in a month (credit limit violations days), and the number of overdue payments at the end of the month (overdue payments).

To test the interaction effects, we consider the following products: CET1 $x$ roa; CET1 $x$ rod; CET1 $x$ roe; CET1 $x$ leverage; CET1 $x$ multiple banking; CET1 $x$ credit line usage; CET1 $x$ credit limit violations days; $C E T 1 x$ overdue payments; CET1 $x$ roa $x$ multiple banking; CET1 $x$ roa $x$ credit limit violations days; CET1 $x$ roa $x$ overdue payments; CET1 $x$ roe $x$ multiple banking; CET1 $x$ roe $x$ credit limit violations days; CET1 $x$ roe $x$ overdue payments.

Correlation matrix and main descriptive statistics for each variable are reported in Table 1.

Table 1. Descriptive statistics and correlation matrix

\begin{tabular}{|c|c|c|c|c|c|c|c|c|c|c|c|}
\hline & Mean & s.d. & 1. & 2. & 3. & 4. & 5. & 6. & 7. & 8. & 9. \\
\hline 1.Credit Grants & -6753.78 & 1.51 & 1 & & & & & & & & \\
\hline 2.Cet1 & 16.79 & 5.12 & .53 & 1 & & & & & & & \\
\hline 3.Roa & .56 & 13.06 & .48 & .10 & 1 & & & & & & \\
\hline 4. $\operatorname{Rod}$ & 20.74 & 1.34 & .21 & .53 & .54 & 1 & & & & & \\
\hline 5.Roe & 17.44 & 2.21 & .25 & .01 & .48 & .19 & 1 & & & & \\
\hline 6.Leverage 2014 & 71.13 & 2.34 & -.18 & .23 & .25 & .58 & .56 & 1 & & & \\
\hline 7.Multiple banking & 1.14 & .437 & -.26 & .33 & -.53 & -.24 & .49 & .47 & 1 & & \\
\hline 8. Credit line usage & 78.57 & 35.76 & -.34 & -.51 & -.12 & .43 & .11 & .32 & .45 & 1 & \\
\hline 9. Credit limit violations $d$ & 8.25 & 5.15 & -.44 & -.39 & -.27 & .12 & .14 & .28 & .38 & .25 & 1 \\
\hline 10.Overdue payments & 1.25 & 1.16 & -.56 & -.54 & -.42 & -.32 & .22 & .34 & .26 & .36 & .52 \\
\hline
\end{tabular}

\subsection{Models}

Our data let us to use panel regression models with fixed effects. We tested the appropriateness of the panel specification against a simple pooled model with the Lagrangian Multiplier Test (LM Test). The LM tests the hypothesis that the variance across entities is zero, which means that significant difference across units does not exist. In our case, the LM test was always significant at a high level $(\mathrm{p}<0,1 \%)$ thus the null hypothesis was rejected (Table 4). Therefore, we specified our model as a panel model with fixed effects.

Specifically, we test four different models. In the first one, we inserte all the independent variables. In the Model 2, we add the interaction terms between CET1 and public available information; then, we add the interaction terms between CET1 and private available information (Model 3); finally, we also consider the interaction terms between CET1 and both public and private available information:

Credit Grants $=\beta 0+\beta 1\left(C E T 1_{i j}\right)+\beta 2\left(\right.$ roa $\left._{i k}\right)+\beta 3\left(\operatorname{rod}_{i k}\right)+\beta 4\left(\right.$ roe $\left._{i k}\right)+\beta 5\left(\right.$ leverage $\left._{i k}\right)+\beta 6\left(\right.$ multiple banking $\left._{i j k}\right)+$ $\beta 7\left(\right.$ credit line usage $\left._{i j k}\right)+\beta 8$ (credit limit violations days $\left._{i j k}\right)+\beta 9$ (overdue payments $\left.s_{i j k}\right)+\beta n$ (interaction terms $\left.s_{i j k}\right)+\varepsilon$

Before to test our models, we control for possible problems of heteroskedasticity and we carry out the control of heteroskedasticity by calculating the robust standard errors using the Huber White Sandwich estimator for clustered data (Rogers, 1993; Wooldridge, 2002). In order to reduce multicollinearity due to the interaction terms, we applied a mean centering procedure.

\section{Results}

In this section, we present the results of the analyses, performed with STATA13. In the column 1 of the Table 2, we find a positive relationship between banks' capitalization (CET1) and credit grants $(\beta=.021 ; \mathrm{p}<.01)$. In other words, 
this means that banks less capitalized are more forced to cut the loans to their clients. Among public available information, we find significant and positive relationships between roa and credit grants $(\beta=.021 ; p<.05)$ and between roe and credit grants (loans $(\beta=.056 ; p<.05)$. Instead, the effects of rod and of leverage are not significant. These findings suggest that firms with a better profitability are preferred in the evaluation for credit supply. Finally, Model 1 highlights that the bank-firm relationship has a strong impact on credit grants. Specifically, the choice to relate with more than one bank (multiple banking) $(\beta=-.016 ; \mathrm{p}<.10)$, the credit limit violations days $(\beta=-.042$; $\mathrm{p}<.01)$, and the presence of overdue payments $(\beta=-.051 ; \mathrm{p}<.05)$ have a negative effect on the dependent variable.

In Model 2, we add the interaction terms between CET1 and firms' public available information finding a positive moderating effect of roa $(\beta=.039 ; \mathrm{p}<.05)$ and roe $(\beta=.032 ; \mathrm{p}<.05)$. Therefore, hypothesis $1 \mathrm{a}$ is supported. This means that wheter firms have good levels of profitability, they are less penalized by banks scarcely capitalized and are awarded by well capitalized banks.

Model 3 reports the effects of firms' private available information interacting with CET1 on credit grants. Three of them negatively moderate the direct relationship between banks' capitalization and credit grants: the multiple banking $(\beta=-.039 ; \mathrm{p}<.05)$, the credit limit violations days $(\beta=-.042 ; \mathrm{p}<.01)$ and the overdue payments $(\beta=-.59$; $\mathrm{p}<.01)$.

In Model 4, the dependent variable credit grants is regressed on the interaction terms among CET1, public available information and private available information. Findings support hypothesis 3 , highlightening that also firms with a good profitability are penalized in credit grants if they do not take care the relationship with the bank.

Table 2. Results of Regression Models

\begin{tabular}{|c|c|c|c|c|}
\hline \multirow[b]{2}{*}{ Variables } & \multicolumn{4}{|c|}{ Credit Grants } \\
\hline & Model 1 & Model 2 & Model 3 & Model 4 \\
\hline Cet1 & $.021 * * *$ & $.025 * * *$ & $.027 * * *$ & $.028 * * *$ \\
\hline Roa & $.021 * *$ & $.033 * *$ & $.032 * *$ & $.044 * *$ \\
\hline $\operatorname{Rod}$ & .011 & .011 & .012 & .015 \\
\hline Roe & $.056^{* *}$ &, $054 * *$ & $.056^{* *}$ &, $058 * *$ \\
\hline Leverage2014 & .019 & .019 & .018 & .018 \\
\hline Multiple banking & $-.016^{*}$ & $-.016^{*}$ & $-.021 *$ & $-.026 *$ \\
\hline Credit line usage & -.054 & -.044 & -.040 & -.034 \\
\hline Credit limit violations days & $-.042 * * *$ & $-.042 * * *$ & $-.046 * * *$ & $-.044 * * *$ \\
\hline Overdue payments & $.051 * *$ & $.049 * *$ & $.055 * * *$ & $-.056 * * *$ \\
\hline CET1 $\times$ roa; & & $.039 * *$ & & \\
\hline CET1 $\times$ roe & & $.032 * *$ & & \\
\hline CET1 x multiple banking; & & & $-.039 * *$ & \\
\hline CET1 $x$ credit limit violations days; & & & $-.042 * * *$ & \\
\hline CET1 x overdue payments; & & & $-.059 * * *$ & \\
\hline CET1 $x$ roa $x$ multiple banking; & & & & $-.039 *$ \\
\hline CET1 $x$ roa $x$ credit limit violations days; & & & & $-.042 * *$ \\
\hline CET1 $x$ roa $x$ overdue payments; & & & & $-.053 * * *$ \\
\hline CET1 $x$ roe $x$ multiple banking; & & & & $-.037 *$ \\
\hline CET1 $x$ roe $x$ credit limit violations days; & & & & $-.034 * *$ \\
\hline CET1 $x$ roe $x$ overdue payments & & & & $-.048 * * *$ \\
\hline $\mathrm{N}$ & 18,143 & 18,143 & 18,143 & 18,143 \\
\hline Adjusted $\mathrm{R}^{2}$ & .320 & .327 & .329 & .332 \\
\hline $\mathrm{F}$ & $9.672 * * *$ & $9.693 * * *$ & $9.889 * * *$ & $10.007 * * *$ \\
\hline \multicolumn{5}{|l|}{$* * * \mathrm{p}<.01$} \\
\hline \multicolumn{5}{|l|}{$* * \mathrm{p}<.05$} \\
\hline$* \mathrm{p}<.10$ & & & & \\
\hline
\end{tabular}




\section{Discussion and Conclusion}

The present paper sought to investigate what affects the credit grants beyond banks'capitalization. Specifically, it aimed at evaluating the contribution of several aspects related to firms' balance sheets information (public available information) and to the bank-firm relationships (private available information). First, it confirms that banks more capitalized provide more loans to their clients (Gallucci et al., 2017b). Besides, with this work, we aim at embracing the demanding perspective (firms). With this aim, we consider firms' publicly and privately information available for banks. Our findings suggest that, while firms' leverage has a non significant effect on the direct relationship between banks' capitalization and credit grants, firms' profitability positively moderates the above-cited relationship. Therefore, firms with a better roa and roe less suffer credit rationing when interface less capitalized banks.

By considering firm-bank relationship (privately information), our results show that multiple banking is not an opportune choice for the firms if they are willing to receive funding. Indeed, firms with a higher number of bank relationship have suffered more of reductions in credit lines. Moreover, also the credit limit violations days and the overdue payments negatively moderates the direct relationship between banks' capitalization and credit grants. Therefore, firms who do not take care the relationship with banks are penalized. This finding is furtherly supported by the negative moderating effect of the coijont publicly and privately information. The just mentioned results give us the opportunity to offer some useful implications for practitioners. First, firms should give more attention to the planning of banks relationship. The respect of the time in refound credit lines determinates their level of reliability. Moreover, while multiple bank could appear as an opportunity, our results reveal that it represents a liability in rationing time. It is an aspect considered by banks in order to provide credit. Hence, a faithful relationship with one bank could be the right way to survival to a reduction of credit crunch, due to the personal link that may be created between bank and firm.

Despite of these interesting preliminary findings, this work needs to be further developed. For example, it could be interesting investigating if the more capitalized banks adopt internal rating mechanisms, which in turn allow them to free resources to provide credit to borrowers. Moreover, it could be useful replying the same analysis, by considering different indexes able to give information about firm's "health state". In this way, the research could provide further useful practical implications for firms and banks.

Besides, our study does not investigate the effect of reductions in credit lines on firms' decisions about their financial structure (Kroll and Cohen, 2000). Firms could compensate this reduction with other sources of debt (Cosci et al., 2015). This means that they should become more transparent. The current economic climate, the benefits arising from the possibility of access to otherwise unavailable resources should overpower the "disclosure" costs. The benefits of diversification of sources of funding, from greater bargaining power in credit relations and reputational gain that may result from access to markets could also be an incentive to openness and transparency. Finally, it would be interesting to understand if the choice to link the firm to a single bank, affordable choice in terms of lower credit rationing, may prove equally suitable than for example the interest rate which the company is subject. Sometimes, for example, it can happen that, by virtue of a binding long-term, the bank can smooth out the effects of monetary tightening on the customer base with which weaves broader relations. In exchange for what the customers of this type correspond to the bank permanently higher interest rates that incorporate a sort of insurance premium. It creates a sort of implicit contract between bank and enterprise that requires a profit and risk sharing (Ferri and Pittaluga, 1997). According to this implicit contract the bank is committed to stabilize the availability and the cost of borrowing for the enterprise; the company undertakes not to abandon the bank in times of abundant credit and cheap.

Finally, in this work, we measure the credit grants as the difference in the level of credit in a year and the previous one, but we do not take into account the actual amount of asked loans, whose requests have not been answered. Finally, we do not consider the purposes for which the request of credit is put forward: will the financing be used for debt restructuring or to fill the increased need for working capital, or to finance investments long term? This would be a further aspect to be investigated and which banks can take into account only if there is a long-term relationship with the company, willing to provide information in accordance with the principle of transparency.

\section{Acknowledgements}

We acknowledge the economic support to the research provided by Fondazione Roma.

\section{References}

Accetturo, A., Giunta, A., \& Rossi, S. (2011). Le imprese italiane tra crisi e nuova globalizzazione. L'industria, 32(1), 145-163.

Aisen, A., \& Franken, M. (2010). Bank Credit during the 2008 Financial Crisis: A Cross-Country Comparison. 
Working Paper (International Monetary Fund), 10(47), 1-26. https://doi.org/10.5089/9781451963120.001

Albareto, G., \& Finaldi Russo, P. (2012). Fragilità finanziaria e prospettive di crescita: il razionamento del credito alle imprese durante la crisi. Banca d'Italia. Questioni di Economia e Finanza, Occasional Paper, 127, 1-44.

Angelini, P., Di Salvo, R., \& Ferri, G. (1998). Availability and cost of credit for small businesses: customer relationship and credit cooperatives. Journal of Banking and Finance, 22(6/8), 925-954. https://doi.org/10.1016/S0378-4266(98)00008-9

Baccarani, C., Golinelli, G.M., \& Rullani, E. (2013). Le BCC banche di territorio. Padova: CEDAM.

Bernanke, B.S., \& Lown, C.S. (1991). The Credit Crunch. Brookings Papers on Economic Activity, 2, 205-247. https://doi.org/10.2307/2534592

Birindelli, G., \& Modina, M. (2010). Imprese, banche e finanza. Le evidenze di un'analisi territoriale alla luce della crisi finanziaria. Milano: Franco Angeli.

Birindelli G., \& Ferretti P. (2011). Il livello e la composizione del capitale nelle banche. In Tutino F., Birindelli G., Ferretti P., Basilea 3. Gli impatti sulle banche, Milano: Egea, 283-324.

Bofondi, M., Carpinelli, L., \& Sette, E. (2013). Credit supply during a sovereign debt crisis. Temi di Discussione Banca D'Italia, 909, 1-59. https://doi.org/10.2139/ssrn.2259657

Bugamelli, M., Cristadoro, R., \& Zevi, G. (2009). La crisi internazionale e il sistema produttivo italiano: un'analisi su dati a livello di impresa. Questioni di Economia e Finanza, Occasional Paper, 58, 1-50.

Burlon, L., Fantino, D., Nobili, A., \& Sene, G. (2016). The quantity of corporate credit rationing with matched bank-firm data. Temi di Discussione Banca d'Italia, 1058, 1-81. https://doi.org/10.2139/ssrn.2778001

Cenni, S., Monferrà, S., Salotti, V., Sangiorgi, M., \& Torluccio, G. (2015, April). Credit rationing and relationship lending. Does firm size matter?. Journal of Banking and Finance, 53, 249-265. https://doi.org/10.1016/j.jbankfin.2014.12.010

Chatterjee, S., \& Hadi, A.S. (2012). Regression Analysis by Example (5th ed.). Chichester: John Wiley \& Sons, Inc.

Cosci, S., Guida, R., \& Meliciani, V. (2015). Leasing Decisions and Credit Constraints: Empirical Analysis on a Sample of Italian Firms. European Financial Management, 21(2), 377-398. https://doi.org/10.1111/j.1468-036X.2013.12019.x

De Bodt, E., Lobez, F., \& Statnik J.C. (2005). Credit Rationing, Customer Relationship and the Number of Banks: an Empirical Analysis. European Financial Management, 11(2), 195-228. https://doi.org/10.1111/j.1354-7798.2005.00282.x

De Mitri, S., Gobbi, G., \& Sette, E. (2010). Relationship lending in a financial turmoil. Temi di Discussione Banca d'Italia, 772, 1-50. https://doi.org/10.2139/ssrn.1788037

Ferri, G., \& Pittaluga, G.B. (1997). Il finanziamento delle imprese nelle fasi di restrizione monetaria. Il caso del credito cooperativo. In Cesarini, F., Ferri, G. \& Giardino, M. (Eds.), Credito e sviluppo. Banche locali cooperative e imprese minori, Bologna: Il Mulino.

Fiordelisi, F., Monferrà, S., \& Sampagnaro, G. (2014). Relationship lending and credit quality, Journal of Financial Services Research, 46(3), 295-315. https://doi.org/10.1007/s10693-013-0176-0

Foglia, A., Laviola, S., \& Reedtz, P.M. (1998). Multiple banking relationships and the fragility of corporate borrowers, Journal of Banking and Finance, 22(10), 1441-1456. https://doi.org/10.1016/S0378-4266(98)00058-2

Gallucci, C., Formisano V., Modina, M., \& Pietrovito, F. (2017a). Estimating the additional predictive power of bankfirm hard information in default models. An analysis on a sample of Italian firms", Eletronic Proceedings of IRMC 2017.

Gallucci, C., Formisano V., Modina, M., \& Santulli, R. (2017b). Le determinanti bank-specific e firm-specific dell'offerta di credito: Un'analisi post-crisi economico-finanziaria, Bancaria, forthcoming.

Guiso, L. (1998). High-tech firms and credit rationing. Journal of Economic Behavior \& Organization, 35(1), 39-59. https://doi.org/10.1016/S0167-2681(97)00101-7

Guiso, L. (2003). Small business finance in Italy. EIB papers, 8(2), 121-149.

Hair, J. (2010). Multivariate data analysis (7th ed.). Upper Saddle River, NJ: Prentice Hall. 
Herrera, A.M., \& Minetti, R. (2007). Informed finance and technological change: evidence from credit relationships. Journal of Financial Economics, 83(1), 223-269. https://doi.org/10.1016/j.jfineco.2005.12.001

Iyer, R., Da-Rocha-Lopes, S., Peydró, J.L., \& Schoar, A. (2013). Interbank liquidity crunch and the firm credit crunch: evidence from the 2007-2009 crisis. Review of Financial Studies, 27(1), 347-372. https://doi.org/10.1093/rfs/hht056

Jiménez, G., Lopez, J.A., \& Saurina, J. (2009). Calibrating exposure at default for corporate credit lines, Journal of Risk Management in Financial Institutions, 2(2), 121-129.

Khwaja, A.I., \& Mian, A. (2008). Tracing the Impact of Bank Liquidity Shocks: Evidence from an Emerging Market. American Economic Review, 98(4), 1413-42. https://doi.org/10.1257/aer.98.4.1413

Kroll, Y., \& Cohen, A. (2000). Alternative Solutions to Underinvestment, Under Equity and Credit Rationing. Journal of Business Finance and Accounting, 27(3/4), 395-421. https://doi.org/10.1111/1468-5957.00318

La Torre M., \& Mango F. (2012). Securitization degli attivi e crisi finanziarie: i ritardi nel downgrading. Bancaria, 9, 54-67.

Leone, P. (2003). Capital management nelle banche: fondamenti teorici, problemi applicativi e implicazioni gestionali del capitale. Padova: Cedam.

Leone, P. (2005). Gestione strategica del capitale in banca: teoria e prassi. Padova: Cedam.

Micucci, G., \& Rossi, P. (2012). Financing R\&D investments: relationship lending or financial markets?. Temi di Discussione Banca d'Italia, 1-32.

Modina, M., \& Pietrovito, F. (2014). A default prediction model for Italian SMEs: the relevance of the capital structure. Applied Financial Economics, 24(23), 1537-1554. https://doi.org/10.1080/09603107.2014.927566

Neter, J., Kutner, M., Wasserman, W., \& Nachtsheim, C. (1996). Applied linear regression models (3rd ed.). Chicago, IL: Irwin.

Norden, L., \& Weber, M. (2010). Credit line usage, checking account activity, and default risk of bank borrowers. Review of Financial Studies, 23(10), 3665-3699. https://doi.org/10.1093/rfs/hhq061

Panetta, F. (2013). Banche, Finanza, Crescita. Speech at the Conference "Oltre la crisi: quale futuro per le banche italiane?", organized by Associazione per lo Sviluppo degli Studi di Banca e Borsa and University Cattolica del Sacro Cuore, Milan.

Paravisini, D. (2008). Local Bank Financial Constraints and Firm Access to External Finance. The Journal of Finance, 63(5), 2161-2193. https://doi.org/10.1111/j.1540-6261.2008.01393.x

Rogers, W. (1993). Regression standard errors in clustered samples. Stata Technical Bulletin, 3(13), 19-23.

Rossi, S. (2013). Finanza e crescita dopo la crisi. Speech at CommunityCib SdaBocconi.

Schnabl, P. (2012). The International Transmission of Bank Liquidity Shocks: Evidence from an Emerging Market. The Journal of Finance, 67(3), 897-932. https://doi.org/10.1111/j.1540-6261.2012.01737.x

Schreft, S., \& Owens, R.E. (1991). Survey Evidence of Tighter Credit Conditions: What Does it Mean?. Working Paper (Federal Reserve Bank of Richmond), 91(5), 29-34. https://doi.org/10.2139/ssrn.2127220

Sette, E., \& Gobbi, G. (2014). Relationship Lending during a Financial Crisis. Journal of the European Economic Association, 13(3), 453-481. https://doi.org/10.1111/jeea.12111

Stiglitz, J., \& Weiss, A. (1981). Credit rationing in markets with imperfect information. American Economic Review, $71(3), 393-410$.

Wooldridge, J. (2002). Econometric Analysis of Cross Section and Panel Data. Cambridge, MA: MIT Press. 